\title{
Epidemijska veksilologija - uporaba zastava u kontroli i prevenciji širenja zaraznih bolesti
}

\author{
Željko Heimer \\ Hrvatsko grboslovno i zastavoslovno društvo, Zagreb, Hrvatska \\ e-mail: zheimer@gmail.com
}

SAŽETAK Rad prikazuje kratak povijesni pregled zastava koje su se koristile kao upozorenje, kontroliranje, odnosno oblik borbe protiv epidemija. Prikazuje se uporaba zastava kao simbola zdravstvene opasnosti i karantene, njihov razvoj te se donose primjeri zastava državnih službi koje su nadležne provoditi zdravstveno-sanitarni nadzor i karantenu kroz povijest. Posebna pozornost posvećena je aktualnoj pandemiji teškog akutnog respiratornog sindroma nazvanog COVID-19 i predstavlja primjere uporabe nacionalnih zastava kao simbola solidarnosti $s$ pogođenim zemljama te razvoj novih zastava koje simboliziraju solidarnost sa zdravstvenim djelatnicima i drugima koji se bore protiv korone, koja je eskalirala u 2020. godini.

Ključne riječi: veksilologija, karantena, zastava signal karantene, zastava zdravstveno-sanitarnih službi, nacionalna zastava, bijela zastava, zastava borbe protiv korone. 


\section{Uvod}

Veksilologija je znanstvena disciplina koja proučava nastanak, razvoj i uporabu zastava kao objekata društvene komunikacije. Interdisciplinarno obuhvaća niz društvenih i humanističkih, ali i drugih znanstvenih područja, a iako se često formalno pribraja pomoćnim povijesnim znanostima u dijelu koji se odnosi na povijesne veksilološke aspekte, veksilolozi je temeljno smještaju u područje sociologije u razmatranju simbola aktualnih društvenih zbivanja kao i socioloških razmatranja značenja zastave u društvu kroz povijest (Smith, 1975.:30). ${ }^{1}$ Tradicionalno se veksilologija bavi proučavanjem uporabe nacionalnih, regionalnih i lokalnih zastava, zastava drugih uobičajenih oblika društvenih organizacija - poput vojnih, sportskih, lovačkih, pjevačkih i drugih jedinica ili udruga. Aktualna pandemija bolesti COVID-19 usmjerava našu pažnju na upotrebu zastava povezanih s mjerama praćenja i prevencije širenja zaraza.

Cilj ovog rada jest dati kratak povijesni pregled zastava koje su se koristile kao upozorenje, kontroliranje, odnosno oblik borbe protiv epidemija. Posebna će pozornost u ovom radu biti posvećena uporabi zastava pri aktualnoj pandemiji teškog akutnog respiratornog sindroma nazvanog COVID-19 (skraćeno od engl. Coronavirus disease 2019) izazvanog virusom SARS-CoV-2 (engl. Severe Acute Respiratory Syndrome Coronavirus 2).

\section{Zastave koje označavaju zdravstvenu opasnost i karantenu}

U svrhu obrane od zaraznih bolesti već se u ranom obliku društvenih zajednica pojavljuju pokušaji sprječavanja širenja zaraze izolacijom zaraženih pojedinaca i grupa. Kod visokozaraznih bolesti s visokim morbiditetom (pobolom) i s izuzetno teškim posljedicama nije uvijek bilo moguće spriječiti širenje, no kod manje infektivnih bolesti sa sporijim napredovanjem simptoma bilo je potrebno izolirane pojedince jasno označiti. Vjerojatno je najpoznatija bolest takve vrste lepra, odnosno guba. Leprozoriji, kao posebna izolirana mjesta u kojima su živjele kolonije gubavaca, spominju se već u antičkim vremenima. Oboljeli od gube označavali su se na razne načine radi održavanja socijalne distance; između ostalog zvučnim signalima, zvoncima te jasno razlikovnom odjećom, bijelim plaštevima s kapuljačama i slično. Izolacija osoba kod kojih bi se uočile promjene na koži spominje se u trećoj knjizi Mojsijevoj, koja se na hrvatskom naziva Levitski zakonik (lat. Leviticus, hebr. Vajikra), u 13. poglavlju koje opsuje postupke u slučaju pojave gube. ${ }^{2}$

\footnotetext{
${ }^{1}$ Usp. „Veksilologija kao područje znanstvenog interesa“ u Heimer, 2013.: 61-72.

${ }^{2}$ Lev 13:4-5 „4Ali ako se pokaže da bjelkasta pjega na koži njegova tijela nije dublja nego i koža, a dlaka na njoj nije pobijeljela, neka onda svećenik bolesnika osami sedam dana. ${ }^{5}$ Neka ga sedmoga dana opet svećenik pregleda. Ako ustanovi svojim očima da zaraza još postoji, ali da se po koži dalje ne širi, neka ga osami još sedam dana.", citat prema prijevodu na Online Biblija, 2012.
} 
Nije poznato jesu li se u to vrijeme koristile i zastave, no to nije ni za očekivati budući da signalizacija pojedinaca i manjih skupina zastavama na kopnu nije osobito učinkovita i praktična. Nije na odmet ni podsjetiti da su trgovačke rute i duga putovanja u pravilu, barem u sredozemnom i europskom kontekstu, značila i plovidbu brodom i da je najvažniji način razmjene ljudi i dobara bio morem i rijekama, što znači da su brodovi iz drugih, udaljenih zemalja sve češće uplovljavali u luke srednjovjekovnih gradova, koji su utvrdama bili dobro zaštićeni od vanjskih prijetnji. U svakom slučaju, prva uporaba zastava kojima se označava postojanje skupina ljudi koji boluju od lako prenosivih, i uz to teških, bolesti pojavljuje se relativno kasnije. Konkretno, njihovo korištenje vezano je za uplovljavanje brodova u luke počevši od kasnog srednjeg vijeka.

Nakon što je sredinom 14. stoljeća velika epidemija kuge ostavila razorne posljedice u cijeloj Europi, sredozemni trgovački gradovi uvode ozbiljne mjere za sprječavanje ponavljanja tog crnog scenarija. Među prvima je bila Dubrovačka Republika, koja je najprije na obližnjim otocima uvela tridesetodnevnu izolaciju (trentina) putnika i tereta brodova koji su dolazili iz zaraženih područja. Slično su slijedile Venecija i druge luke. Sredinom 15. stoljeća taj je period čekanja povećan na 40 dana (karantina) (Lang, 1994.:67).

U raznim vremenima i područjima koristile su se različite zastave za signalizaciju opasnosti od zaraze koju brod sa sobom donosi. Zabilježena je uporaba crnih ili zelenih zastava u tu svrhu ${ }^{3}$, no najpoznatija i najraširenija bila je uporaba žute zastave. Naime, žutim su se oznakama označavale u europskim gradovima kuće u kojima su boravili kugom zaraženi, a žuta boja korištena je i inače za označavanje osoba koje su na određeni način isključene iz redovnog života. Iz istog običaja razvio se u srednjem vijeku i žuti znak za označavanje Židova u obliku velikog žutog diska ili žutog šešira (Ansbacher, 2008.).

Tako se brodovi koji dolaze u luku identificiraju isticanjem žute signalne zastave „karantine" sve do provedbe inspekcije lučkih sanitarnih vlasti i do trenutka kada dobiju dozvolu za „slobodnu praksu“ - dozvolu za obavljanje poslova u luci.

Žute se zastave kao signali za karantenu, odnosno za potrebu sanitarne inspekcije, redovito pojavljuju u signalnim pomorskim priručnicima u 19. stoljeću, a žuta se zastava kao oznaka za slovo „Q“ („quebeck“) uključuje u Međunarodni signalni kodeks (Holland, 1953.), odnosno i u inačice sustava signala zastavama u pomorstvu koje su mu prethodile u uporabi u britanskoj trgovačkoj mornarici (Kent, 2009.).

3 Npr. zelenu zastavu za oznaku broda u karanteni na postaji Cuxhaven propisuje sredinom 19. st. Slobodni hanzeatski grad Hamburg (Gaedechens, 1855.:56). Sličnu praksu u Danskoj navodi Le Gras (1858.:17), a isto bilježi još u 20. stoljeću Flaggenbuch, 1926.:25. 
Slika 1. Zastava karantene SAD-a (Norie i Hobbs, 1848.:T. IV.), Slika 2. Zastava karantene Ujedinjenog Kraljevstva (Figsbee, 1856.:16), Slika 3. Zastava karantene SAD-a (Prebl, 1872.:Pl. XI.), Slika 4. Zastava karantene Kraljevine Italije (Flaggenbuch, 1926.:63)

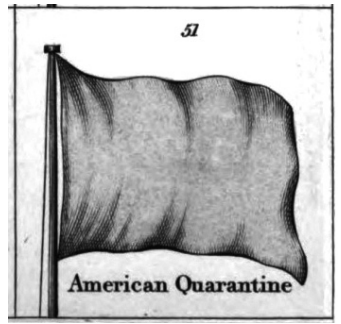

1.

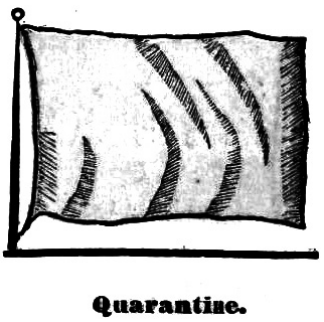

2.

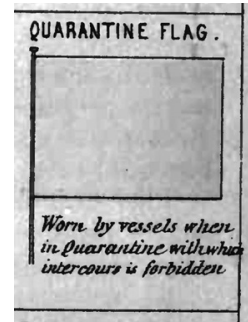

3.

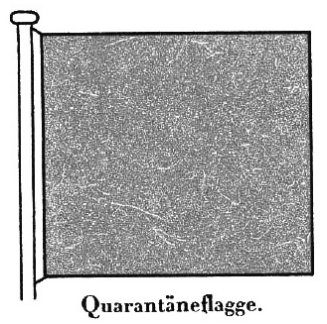

4.

Ipak, zanimljivo je da je žuta zastava za slovo „Q“ u Međunarodnom signalnom kodeksu (ICS), koji je usvojen na međunarodnoj konferenciji 1889. godine u Washingtonu, usvojena za signalizaciju potpuno suprotnog značenja od tradicionalnog. Žuta zastava od tada se, kao i u novijim inačicama ICS-a, rabi da signalizira da je brod prošao sanitarnu inspekciju i da mu je odobrena „slobodna praksa“. Brod u luci koji je „zdrav“ ističe žutu signalnu zastavu, brod koji je „sumnjiv“ (postoji sumnja da bi se mogla

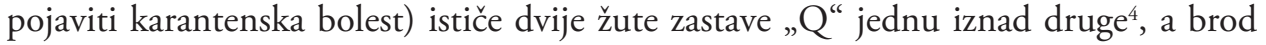
koji je zaražen i u karanteni ističe žutu zastavu „Q“ iznad zastave „L“ („lima“) - raščetvorena u žuta i crna polja. Zastava „L“ navodi se, primjerice, kao francuska zastava karantene 1926. godine (Flaggenbuch, 1926.:31). Međunarodni signalni kodeks definira i niz drugih signala od dviju zastava koji se koriste u postupku provedbe sanitarne inspekcije broda, a postoji i niz od triju zastava, koji se koristi u razmjeni medicinskih informacija. No ti složeniji zastavni signali danas su uglavnom zamijenjeni bežičnom elektroničkom komunikacijom (National Imagery and Mapping Agency, 2003.).

Slika 5.

Detalj karantenskih signala iz Brown's Signal Reminder, (Brown, Son and Ferguson, 1960.)

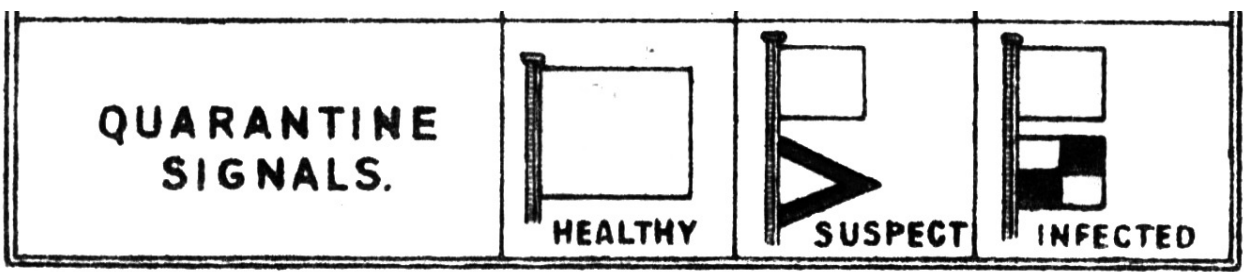

\footnotetext{
${ }^{4}$ Brodovi koji nemaju dva skupa signalnih zastava umjesto druge zastave „Q“ ističu zastavu „1. zamjenska“, žutu trokutastu zastavu s plavim rubom duž vanjskih stranica.
} 


\section{Zastave koje označavaju karantenske službe i ustanove}

Značajne pomorske sile u svoja vremena razvile su i svoje nacionalne signalne kodove, koji su uključivali i simbole vezane za karantenu, i za službe koje su bile nadležne za provođenje tih propisa. Ovdje su prikazane zastave raznih zemalja kao ilustracija, dok sustavno istraživanje tog specifičnog veskilološkog područja izlazi daleko izvan okvira ovog rada.

Primjerice, u japanskoj trgovačkoj mornarici od „otvaranja“ Japana u 19. st. do danas korišten je cijeli niz signala koji su bili propisani da označavaju karantenu na brodovima: počevši 1879. godine od obične žute zastave, koja je 1902. zamijenjena zastavom okomitih pruga crveno-bijelo-crveno $s$ tanjom crvenom vodoravnom prugom kroz sredinu (tako crveni dio čini slovo H), koja je ranije, 1889. godine, propisana za zastavu lučkog upravitelja. Ta je bila propisana do 1921., iako se u jednoj japanskoj karti zastava iz 1913. godine za karantenu prikazuje bijela zastava žutog ruba s crnim piktogramom kandži pisma 検 (ken, za japansku riječ keneki - karantena). Kako god, 1921. godine propisana je za signal karantene na brodu plavo-žuta dvobojnica (načelno jednaka, očito sasvim slučajno, današnjoj zastavi Ukrajine), koja je 1948. zamijenjena bijelom zastavom sa žutim pravokutnim poljima koja prikazuju stilizirano slovo „Q“. Ubrzo se zamijetilo da takva zastava nije dobro uočljiva na moru, te je 1954 . godine zamijenjena žuto-plavom dvobojnicom sa stiliziranim slovom „Q“ u uglu, kakva se koristi i danas. ${ }^{5}$

Slika 6.

Zastave karantene za brodove u Japanu (Crteži Nozomi Kariyasu).

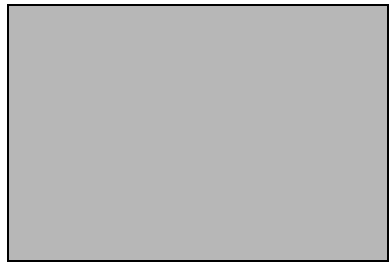

1879. - 1902.

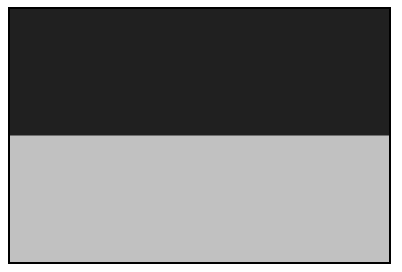

1921. - 1948.

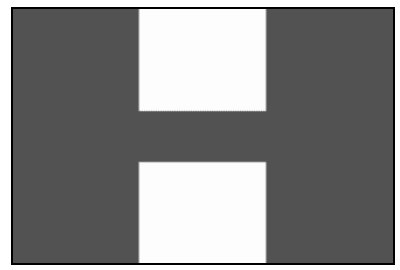

1902. - 1921.

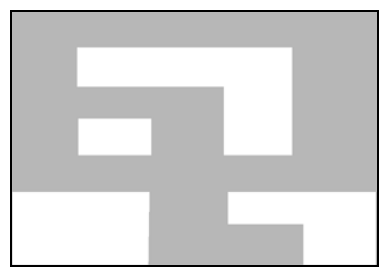

1948. - 1954.

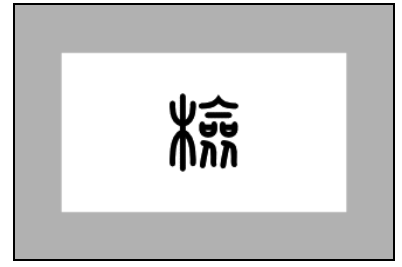

1913.

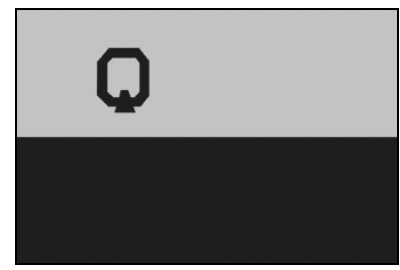

1954. - danas

${ }^{5}$ Izvor: japanska brošura „Povijest karantenskog sustava u Japanu“ Ministarstva javnog zdravstva, citirana u Kariyasu, 2000. 
Najstarije zabilježene zastave koje su se rabile kao pomorski signal karantene u carskoj Rusiji također su žute. Uspostavljene su 1800. godine s ustrojavanjem „službe pograničnih i lučkih karantena“, što se ponavlja i u regulativi iz 1832. godine. Tri godine kasnije uvedena je posebna krmena i pramčana zastava ${ }^{6}$ za brodove karantenske službe, koja kombinira ruski nacionalni simbol kosog (Andrijinog) križa, prikazanog bijelim, tradicionalnu žutu boju karantene u poljima iznad i ispod te zelenu boju zastava državnih pomorskih vlasti lijevo i desno. Brodovi u karanteni i dalje ističu žute zastave, što je i prikazano u prvom francuskom pomorskom priručniku zastava Album des Pavillons iz 1858. godine (Le Gras, 1858.:54-59). To potvrđuje i ruski Альбом штандартов, флагов и вылиелов iz 1869. godine (Gidrografičeski departament Morskago ministerstva, 1869.). No carskim ukazom od 1. ožujka 1871. godine određeno je da „budući da karantenski odjel ne raspolaže ni parobrodima ni jedrenjacima, zastava koja sada postoji se ukida, čamci na vesla trebaju isticati na krmi zastavu prema priloženoj slici.“ Zastava je jednobojna žuta. Žuta je zastava kao signal propisana za brodove koji trebaju proći sanitarnu inspekciju daljnjom regulativom iz 1886. godine. ${ }^{7}$

Slika 7.

Signalne zastave karantene te krmena i pramčana pomorska zastava brodova ruskog „Brandwachta i drugih brodova karantenskog odjela", 1869.

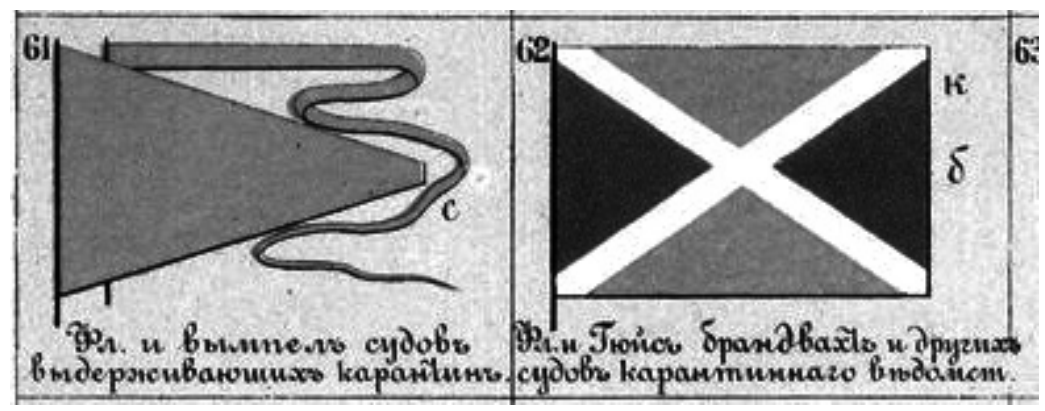

U Australiji bilježimo posebnu krmenu pomorsku zastavu Australske karantenske službe (Australian Quarantene Service), koja je oblika plave australske nacionalne zastave sa žutim diskom dodanim u sredinu donje polovice, u kojem su ukršteni sidro i Eskulapov štap sa zmijicama nadvišeni krunom. Ta se zastava rabila do 1935. godine. Nakon 2. svjetskog rata služba koristi oznaku u kojoj su ukrštene dvije zastave povezane s karantenom - signalne zastave „Q“ $\mathrm{i}$ „L“.

${ }^{6}$ Za razliku od ranije spominjanih signalnih zastava, koje se ističu na signalnom jarbolu uz nacionalne oznake na krmi, krmena i pramčana zastava primarno služe označavanju nacionalne pripadnosti broda, a onda u nekim slučajevima i određenih službi i statusa broda. Usp. Smith, 1975.:19-31.

${ }^{7}$ Prikaz razvoja karantenskih zastava u carskoj Rusiji prema Карантинная служба u Lomantsov, 2010. 
Slika 8.

Zastava Australske karantenske službe, 1908. - 1935. i oznaka u uporabi od oko 1960. do oko 1999. godine (Zbirka Johna Vouughana, Sydney, Australija).
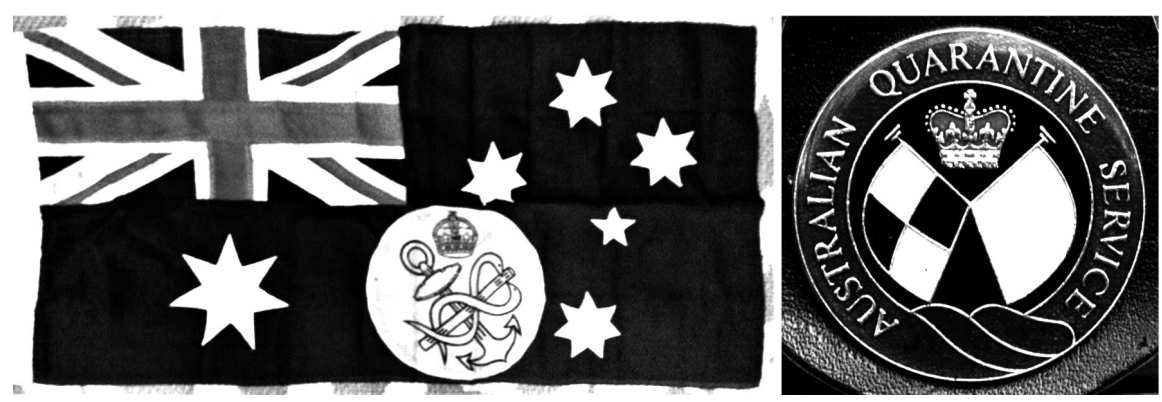

Zastava brodova zdravstvene inspekcije u Republici Turskoj uspostavljena je nakon 1. svjetskog rata i nije se u temelju mijenjala do danas - to je žuta zastava s turskom zastavom u uglu (crvena s bijelim polumjesecom i petokrakom zvijezdom) (Flaggenbuch, 1939.:174.; Pedersen, 1971.; Pierre, 1990.). Čini se da je danas napuštena, jer se u novijim izdanjima francuskog Albuma više ne spominje (Du Payrat, 2000.).

Zanimljivu varijaciju signalne zastave brodova u karantenskoj službi bilježimo početkom 20. stoljeća na Kubi: žuta zastava s crnim znakom koji prikazuje sidro s lancem, plosnati križ sa zvijezdom petokrakom u sredini (slika 469 u McCandless i Grosvenor, 1917.).

Neobičnu varijaciju propisuju i još važeći propisi iz 1924. godine Kraljevine Tonge, koji za plovila koja obavljaju zadaće karantene moraju isticati dvobojnu crveno-žutu zastavu s plavim slovima „M.O.H“ (Ministry of Health) u sredini (Kingdom of Tonga, 1988.).

Slika 9. Zastava brodova turske zdravstvene inspekcije, oko 1920. - oko 1990. (Crtež ŽH), Slika 10. Zastava brodova karantenske službe Kube, oko 1917. (Crtež ŽH), Slika 11. Zastava plovila u zadaći karantene Kraljevine Tonga, od 1924. (Crtež ŽH).

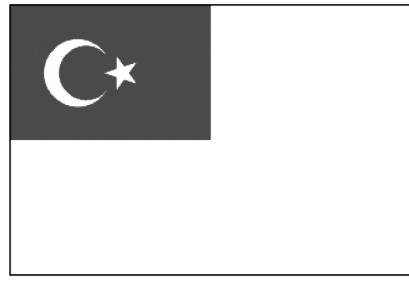

9.

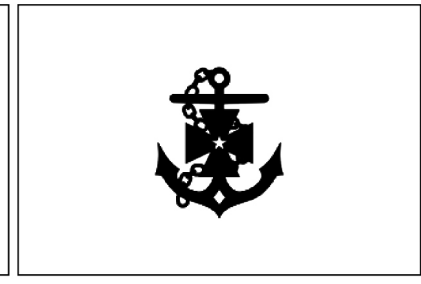

10.

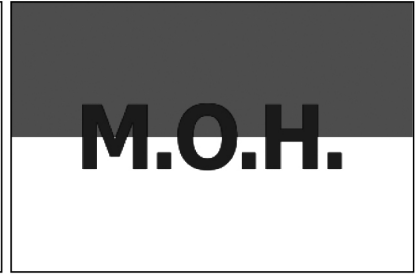

11.

U Sjedinjenim Američkim Državama iz tradicionalne žute zastave karantene razvila se zastava Javne zdravstvene službe (Public Health Service, PHS), uniformirane službe koja djeluje u sklopu Ministarstva zdravstva i ljudskih usluga (Ministry of Health and 
Human Services), a koja je nadležna i za poslove karantene. Čelnik službe nosi naslov Surgeon General i ima čin admirala, njegovi zamjenici i pomoćnici činove viceadmirala i kontraadmirala, a časnici Službe nose odore slične ratnoj mornarici i odgovarajuće činove. U žutoj zastavi smješten je plavi znak Službe: ukršteni kaducej i sidro s lancem, okruženi kružnim natpisom „U.S. Public Health Service 1798“ (Department of Health, Education, and Welfare, 1978.). Zastava se ističe na svim postajama koje koristi ta Služba i kao signal na plovilima u njezinoj službi. Iako je sama služba znatno starija, kao što indicira godina u natpisu, zastava je propisana 1912. godine i to bez natpisa, a natpis je dodan nakon 2. svjetskog rata. Sličnu zastavu na bijeloj odnosno plavoj podlozi s pečatom sličnog sadržaja bijele pozadine rabile su slijedom i njezine prethodnice Marine Hospital Service od 1870. te Public Health and Marine Hospital Service od 1902. godine. Postoje i zastave najviših dužnosnika koje variraju boje elemenata, slično admiralskim zastavama u ratnoj mornarici.

Slika 12.

Zastave Javne zdravstvene službe SAD-a (Flaggenbuch, 1926.:116.)

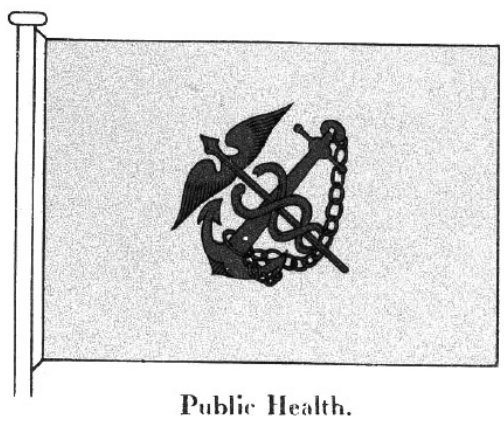

Slika 13.

Suvremena zastave Javne zdravstvene službe SAD-a (Department of Health, Education, and Welfare, 1978.)

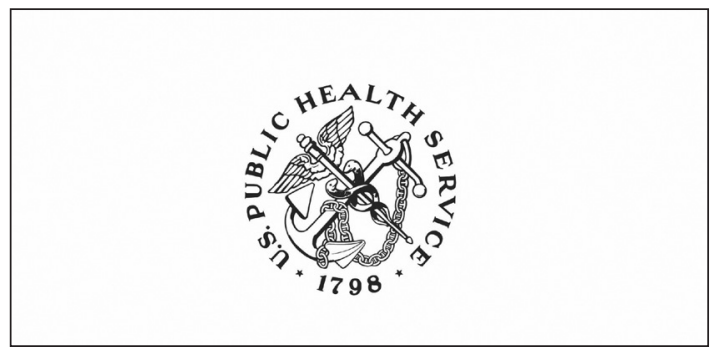

Između dva svjetska rata Republika Argentina ima čak tri zastave vezane za zdravstvenu službu na moru - okomito dvobojni bijelo-plavi signal službujućeg liječnika, bijelu zastavu s crvenim križem kao signal brodova bolnica te žutu zastavu s plavim slovom „S“ kao razlikovnu zastavu sanitetskih plovila (Flaggenbuch, 1926.:11). Sličnu zastavu crvene boje s bijelim slovom „S“ u isto vrijeme ima i Brazil (Flaggenbuch, 1926.:14). 
Slika 14.

Signalne zastave u uporabi u argentinskoj mornarici: službujući liječnik, brod bolnica, sanitetska plovila; iz Flaggenbuch, 1926.

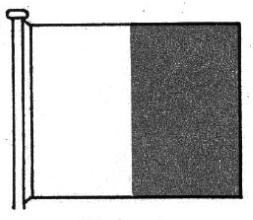

Flagge des wachhabenden Arztes.

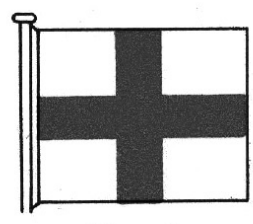

Flagge der Hospitalschiffe.

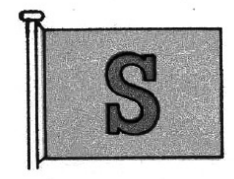

Unterscheidungsflagge der Sanitätsfahrzeuge.

S druge strane, u Kanadi je žuta zastava i danas, unatoč Međunarodnom signalnom kodeksu, propisani znak zaraze na brodovima (Canada Border Service Agency, 1998.), a takva je uporaba opisana u medicinskoj znanstvenoj literaturi barem od 1899. godine $^{8}$. Slično je propisano pravilnicima o karanteni brodova na Filipinima 1992. godine. ${ }^{9}$ Ostaje nejasno kako se u tim zemljama razaznaje je li brod označen žutom zastavom kao zdravstveno „čist“ sukladno međunarodnim propisima ili kao „zaražen“ u karanteni prema lokalnim propisima, no možemo se samo nadati da se zabune u tome ne bi smjele dogadati.

\section{Uporaba nacionalnih zastava vezano za pandemiju bolesti COVID-19}

Sa širenjem zaraze iz inicijalnog žarišta u Kini pojavljuje se međunarodna svijest i izražavanje solidarnosti sa zaraženim nacijama uporabom njihovih zastava u raznim umjetničkim interpretacijama. Ubrzanim globalnim širenjem tih uradaka društvenim mrežama oni su gotovo istovremeno postali viralni i poznati širom svijeta. Prepoznatljive građevine u cijelom svijetu obasjavane su prikazima motiva zastava zemalja $s$ kojima se iskazuje solidarnost, prije svega u prvom krugu najpogođenijim zemljama, NR Kinom i Italijom, a ubrzo i drugima. Možda najpoznatija takva instalacija, koja je putem društvenih mreža postala odmah dio svjetske kulturne baštine, fotografija je monumentalne skulpture Krista Spasitelja iznad Rio de Janeira u Brazilu (Kennedy, 2020.), obasjana nizom nacionalnih zastava pandemijom pogođenih zemalja ${ }^{10}$.

8 „Jan. 27, 1899 - The ship arrives in Halifax Harbour and hoists the yellow quarantine flag from its mainmast, a signal that a quarantine inspection is required." iz dnevnika grofa Sergeja Lavoviča Tolstoja citira Cameron, 2006:1600-1602.

9 „Any vessel subject to quarantine inspection shall be considered in quarantine until given a pratique. Such vessel shall fly a yellow flag at its foremast, drop its anchor at the designated quarantine anchorage, put down its accommodation ladder, wait for the Quarantine Medical Officer...", Administrative Order No. 118-C, 1992. (Republic of the Philippines Department of Health, 2007.)

10 Barem ih tako nazivaju u izvorima, iako se autoru čini da je izbor zastava za svjetlosnu projekciju bio naprosto isječak abecednog prikaza zastava nezavisnih zemalja svijeta, bez obzira na status pogođenosti zarazom. Među prikazanim zastavama pojavljuju se, primjerice, i zastave Crne Gore i NDR Koreje, koje još dugo nakon toga nisu imale službeno potvrđene slučajeve zaraze. 
Slika 15.

Skulptura Krista Spasitelja, Rio de Janeiro, Brazil obasjana zastavama, 18. ožujka 2020.

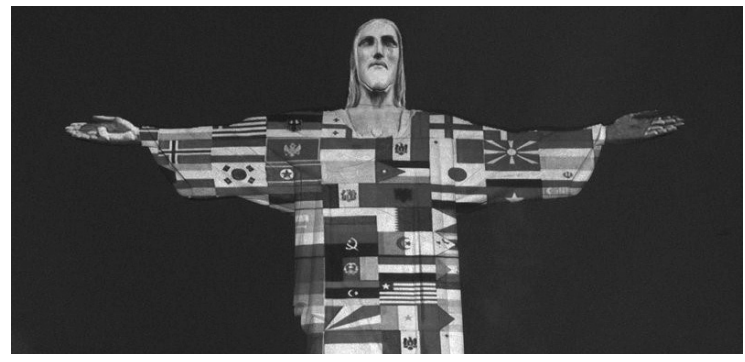

(Izvor: Silvia Izquierdo/AP).

Na društvenim mrežama i kroz druge medije postala je globalno poznata slika (najčešće kopirana bez navođenja izvora i umjetnika) filipinskog umjetnika Christiana Joya Trinidada iz Bulakana, koji ju je naslovio Maskcommunication (igra riječi Mask prema izrazu Mass-Communication), koja prikazuje niz lica različitih fizionomija prekrivenih zaštitnim maskama oslikanim u boje nacionalnih zastava (CNN Philippines, 2020.; RiceFeed, 2020.; CJ Trinidad, 2020.). Trinidad komentira svoj rad: „Unatoč našoj različitosti, jedinstvo i razumijevanje danas su najvažniji“.

Što se simbolike zastava tiče, zanimljivo je primijetiti da su se ubrzo nakon objave pojavile na društvenim mrežama inačice te slike kod kojih je izvorno palestinska zastava na licu lika u sredini slike koji na glavi nosi kefiju ${ }^{11}$ zamijenjena prikazom zastave Saudijske Arabije ili Izraela, očito prema političkim preferencijama onoga koji sliku dijeli na mreži (Hribovšek, 2020::8).

Slika 16.

Fotografija slike C. J. Trinidada Maskcommunication, akril na platnu.

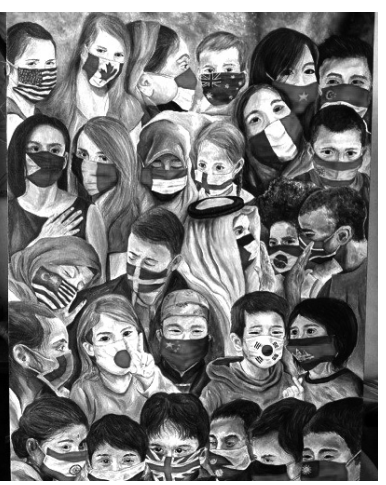

(Izvor: Silvia Izquierdo/AP).

11 Kefija ili kufija - (prema gadu Kufa u današnjem Iraku) tradicionalna arapska marama koja se nosi na glavi, slobodno ili učvršćena agalom, dvostrukim prstenom od odebljeg, obično crnog, užeta. 
Slika 17.

Tri varijacije zastave lika na slici Maskcommunication, detalji iz reprodukcija podijeljenih na društvenim mrežama.

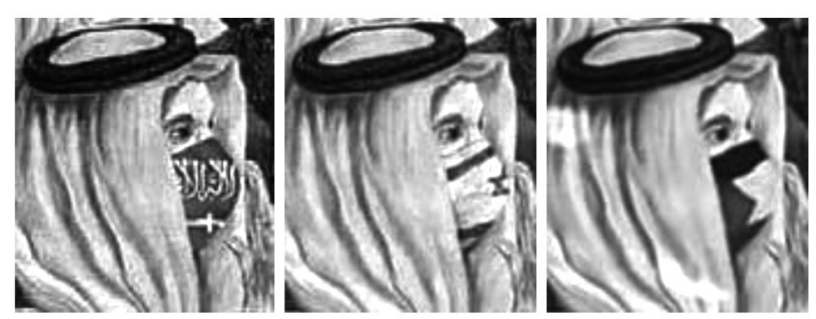

\section{Nove zastave vezane za pandemiju bolesti COVID-19}

Da bi iskazali solidarnost i potporu u borbi protiv pandemijske zaraze, mnogi pojedinci i organizacije počeli su rabiti posebno osmišljene ili reinterpretirane stare zastave. Među prvima koja je tako upotrjebljena tradicionalna je žuta zastava karantene, upravo zbog čega je ovaj rad naprijed i posvetio toliko mjesta njezinu razvoju.

Slika 18.

Zastava korona virusa (Crtež Steffan Giadach Axt).

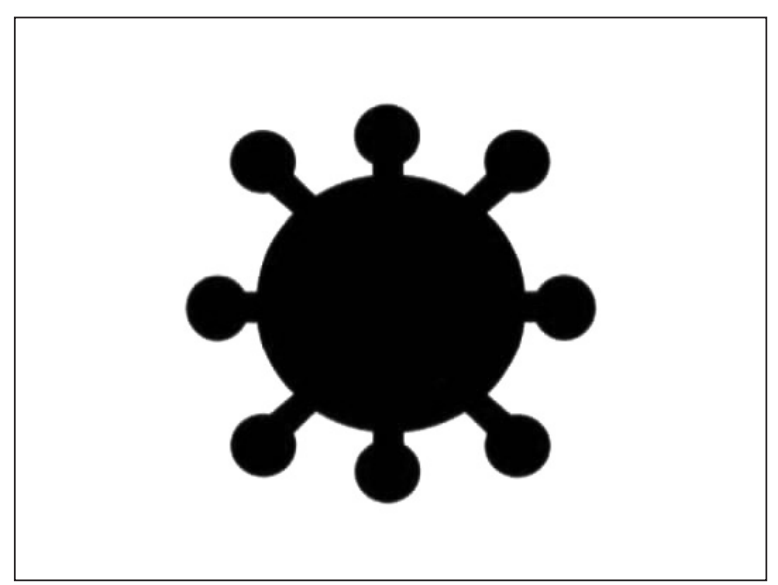

No obična žuta zastava, pokazalo se, nije osobito izražajna za sentiment koji se željelo pokazati. Drugi su pribjegli isticanju signalne zastave „Lima“ - žuto-crno četvorene, koja također nije osobito jasna onima koji nemaju pomorskih znanja. Među pokušaje iznalaženja specifične i jasne zastave spada i varijacija žute zastave s crnim slovom „Q“ u uglu. Čileanski veksilolozi predložili su varijaciju žute zastave s crnim likom koji prikazuje virion (virusna čestica) korone (crni disk s osam kratkih izboja s po kuglicom na kraju) (Giadach Axt, 2020.). Spomenuti primjeri uglavnom se odnose na isticanje zastava od privatnih osoba u Sjevernoj i Južnoj Americi. 
Slika 19.

Zastava istaknuta na Lazaretto Museum, Philadelphia, Pennsilvanija, SAD (Foto Friends of the 1799 Lazaretto Interpretive Museum, 2020.)

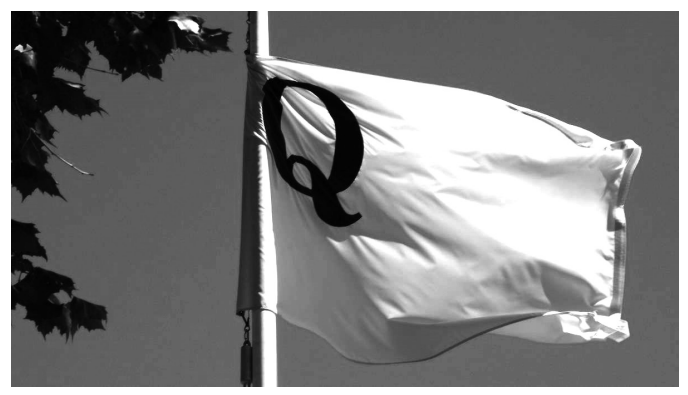

U drugoj polovici ožujka u Belgiji se spontano pojavio pokret izražavanja solidarnosti $s$ medicinskim osobljem koje je u tom trenutku već tjednima najintenzivnije radilo u preopterećenim uvjetima zdravstvenog sustava koji teško podnosi toliki broj pacijenata. Belgijanci su na svojim domovima počeli isticati bijele zastave - bez ikakvih dodatnih simbola, kao boju koja je karakteristična za odore liječnika, medicinskih sestara i tehničara. U toj akciji pridružio im se i belgijski kraljevski dvor, istakavši bijelu zastavu 23. ožujka 2020. godine te objavivši fotografiju palače na svojem Twitter profilu (Belgian Royal Palace, 2020.).

No bijela zastava ima u veksilologiji, ali i u okviru općeg znanja široke populacije, odavno uspostavljeno značenje sasvim drugačijih konotacija. Bijela zastava tradicionalno označava predaju ili spremnost, odnosno poziv na pregovore (o uvjetima predaje), stoga koliko god spontano snažna i simbolična bila belgijska akcija, nije se proširila u druge europske zemlje i dalje.

Slika 20.

Kraljevska palača ističe bijelu zastavu solidarnosti s medicinskim osobljem, 23. ožujka 2020. (Foto Belgian Royal Palace, 2020.)

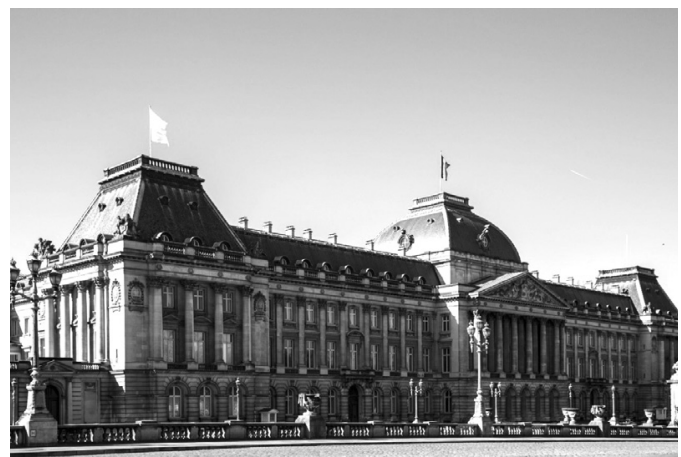


Neke zemlje, pojedine njihove organizacije ili institucije, pozvale su građane koji „ostaju doma" u izolaciji, kao metodi smanjivanja socijalnog kontakta čime se reducira mogućnost širenja zaraze, da istaknu nacionalne zastave. $\mathrm{Na}$ koncu konca, isticanje zastave na domu odnosno mjestu na kojem se boravi oduvijek je bio jedan od glavnih načina uporabe zastava. Tako bilježimo masovno isticanje zastave u Italiji, koja je početkom ožujka bila ovom pandemijom najjače pogođena europska zemlja. Poziv za isticanje nacionalnih zastava na domovima uputilo je i slovensko nacionalno grboslovno, rodoslovno i zastavoslovno društvo Heraldica Slovenica 15. ožujka 2020. godine (Heraldica Slovenica, 2020.a), o čemu su izvijestili mnogi slovenski mediji (npr. Slovenske novice, 2020.; Times.si, 2020.).

Slika 21.

Plakat za akciju Izobesi zastavo društva Heraldica Slovenica, 15. ožujka 2020. prikazuje zastavu na mjestu na kojem je prvi puta istaknuta slovenska trobojnica 7. travnja 1848. u Wolfovoj ulici broj 8 u Ljubljani.

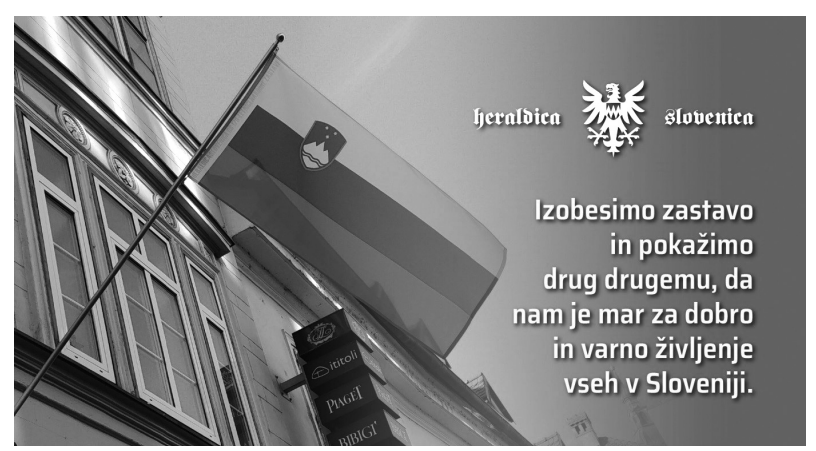

Ipak, u trenutcima globalne krize, u vrijeme trenutno povezanog globalnog sela, ubrzo se pokazalo da patriotske akcije tog tipa nisu dovoljno obuhvatne, što je među prvima shvatilo i spomenuto slovensko društvo. Članovi društva primili su se posla i dizajnirali posebnu zastavu kojom se izražava borba protiv zarazne bolesti COVID-19, kolokvijalno zvane korona.

Društvo Heraldica Slovenica objavilo je izgled nove zastave 25. ožujka 2020. godine. Iz objave prenosimo: „Mi u društvu Heraldica Slovenica oduševljeni smo inicijativom da potpora herojskim zdravstvenim djelatnicima dobije svoj simbolični iskaz zastavom. [...] Tako smo u Heraldici Slovenici nadogradili postojeću inicijativu ${ }^{12}$ sim- $^{-}$ boličnim isticanjem nade koji ujedinjuje sve ljude: pobjeda zdravlja nad epidemijom COVID-19. Na postojeće bijelo polje stavljamo simbol zdravstvenih djelatnika (Eskulapov štap), koji se uzdiže iznad prevrnute i poražene krune (lat. corona)" (Heraldica Slovenica, 2020.b).

Koronavirusi (od kojih je onaj koji izaziva COVID-19 tek jedna vrsta) dobili su ime upravo po kruni - naime, virusne čestice pod elektronskim mikroskopom izgledaju

${ }^{12}$ Misli se na naprijed spomenutu inicijativu isticanja bijelih zastava u Belgiji. 
kao kugla iz koje izrasta niz istoka sa zadebljanjima na vrhu, slično klasičnoj heraldičkoj kruni s perlama na izbojima. Stoga je izbor takve heraldičke krune, prikazane naopako i potrgano, simbolički prikaz pobjede nad tom bolesti, a protagonisti te pobjede zdravstveni su djelatnici simbolizirani svojim tradicionalnim i međunarodno prepoznatljivim znakom, koji ima izvorište u grčkoj mitologiji. Eskulapov štap, oko kojeg se omata zmija, globalno je prihvaćen i prepoznatljiv simbol zdravstva. Eskulap (Asklepije, grč. A $\sigma \kappa \lambda \eta \pi \imath o ́ \varsigma)$ je u grčkoj mitologiji sin Apolona i liječnik bogova, a njegov je ikonografski atribut upravo štap oko kojeg se omotava zmija.

Slika 22.

Zastava borbe protiv korone, prema oblikovanju društva Heraldica Slovenica. (Crtež HS)

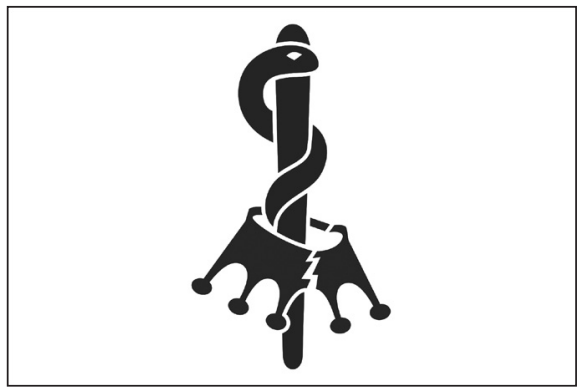

Slika 23.

Prva javna uporaba zastave borbe protiv korone, Odjel za infektivne bolesti Opće bolnice Celje, 2. travnja 2020. (Foto Splošna bolnica Celje, 2020.)

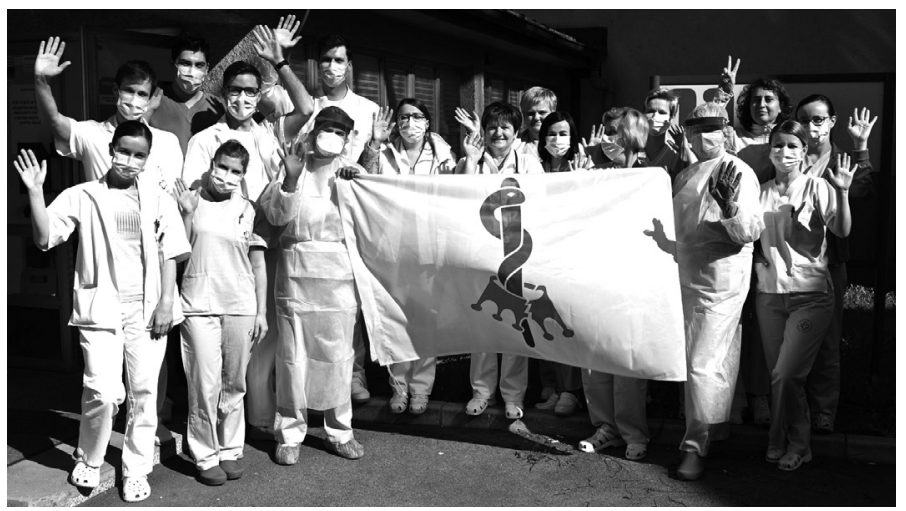

Društvo Heraldica Slovenica ponudilo je grafičke predloške i vektorski prikaz te zastave svim zainteresiranima i simbol se, kao i mnogi drugi naprijed spomenuti simboli borbe protiv pandemije, ubrzo raširio društvenim mrežama, u obliku crteža ili dodatka u podnožju korisničkih profilnih fotografija i drugačije. Nije trebalo dugo čekati da se izradi i prva stvarna zastava tog dizajna, koju je prvo istaknuo tim zdravstvenih djelatnika Odjela za infektivne bolesti Opće bolnice Celje 2. travnja 2020. godine. 


\section{Zaključak}

Zastave koje označavaju zdravstvenu opasnost i karantenu razvile su se prvenstveno kao pomorski signali u pomorskoj trgovini u srednjem vijeku, osobito nakon velike epidemije kuge sredinom 14. stoljeća.

Kao karakteristični pomorski signali, koji su u pravilu vidljivi i s kopna, zastave karantene, karantenskih službi i signala u zdravstveno-sanitarnim poslovnima u luci ostale su i danas među najpoznatijim pomorskim signalnim zastavama, dio opće kulture, poznate i onima koji s pomorstvom imaju malo ili nikakve veze. To se osobito odnosi na žutu zastavu, koja je nekada označavala brodove koji su bili zaraženi ili zdravstveno sumnjivi, a danas je u međunarodnoj pomorskoj signalizaciji simbol broda koji je zdravstveno ispravan.

Posebne zastave razvile su se za označavanje plovila i instalacija zdravstveno-sanitarnih službi nadležnih za provedbu karantene, osobito krajem 19. stoljeća, na vrhuncu suvremenog pomorskog prometa robe i ljudi u industrijskom dobu. Takve službe osobito važnu ulogu imale su u ,prekomorskim“ zemljama, a i danas imaju velik značaj u zaštiti domaćih ljudi i lokalne flore i faune u izvaneuropskim zemljama. Iako te službe postoje i u Europi, njihova uloga u uglavnom kopnenom transportu između europskih zemalja znatno je manje vidljiva u javnosti.

Pojava zarazne bolesti COVID-19 krajem 2019. godine u NR Kini i njezino rapidno globalno širenje u obimu nezabilježenom do sada, a u kontekstu mogućnosti suvremenih globalnih komunikacija ne samo medijima nego i društvenim mrežama, imala je utjecaj na sve sfere društva. To se očituje i u uporabi zastava kao simbola komunikacije unutar društvene grupe i prema drugim grupama. Nacionalne zastave postaju važno sredstvo komunikacije i izražavanja solidarnosti s onima koji su pogođeni zarazom. Reinterpretacije poruka s uporabom nacionalnih zastava brzo se šire društvenim mrežama i imaju snažan utjecaj. Osim toga, u mnogim zemljama, osobito onima koje ranije nisu bile osobito sklone isticanju nacionalnih zastava, dolazi do pojave masovnog isticanja nacionalne zastave kao simbola nacionalne solidarnosti i podvrgavanja pojedinaca višem cilju zaštite društva izolacijom u svojem domu.

No u globalnom svijetu, gdje se poruke šire daleko izvan nacionalnih granica, nacionalne zastave pokazale su se kao nedovoljne i počinju se rabiti nove ili reinterpretirane stare zastave kao simboli globalne solidarnosti i zajedničke borbe protiv ove bolesti. 


\section{Literatura i izvori}

1. Ansbacher, B. Mordechai (2008). Jewish Identification: Jewish Badge. Encyclopaedia Judaica. The Gale Group. https://www.jewishvirtuallibrary.org/jewishbadge. (Pregledano 02.12.2018.)

2. Belgian Royal Palace (2020). Solidair met alle zorgpersoneel en dankbaar voor hun eindeloze inzet. Solidarité et gratitude à l'égard de tout le personnel soignant. @MonarchieBe, Twitter, 23. ožujka 2020. https://twitter.com/MonarchieBe/status/1242043522947170307. (Pregledano 28. ožujka 2020.)

3. Brown, Son and Ferguson (1960). Brown's Signal Reminder All Methods: International Code, Semaphore and Morse. Glasgow: Brown, Son and Ferguson, [n.d.] oko 1960.

4. Cameron, I. (2006). Sergey Tolstoy and The Doukhobors: The Halifax Quarantine. Canadian Medical Association Journal, 174 (11): 1600-1602.

5. Canada Border Service Agency (1998). „Section 15, Quarantine Regulations“, Memorandum D3-5-1, 11 February 1998. Ottawa: Canada Border Service Agency.

6. CJ Trinidad (2020). @cjtrinidad_08, Instagram, 18. ožujka 2020. https://www. instagram.com/cjtrinidad 08/. (Pregledano 20. ožujka 2020.)

7. CNN Philippines (2020).@CNNPhilippines, Facebook,29. veljače 2020. https:// www.facebook.com/CNNPhilippines/posts/look-an-artist-shows-through-hismasterpiece-the-importance-of-communication-amo/2748957442010804/. (Pregledano 10. ožujka 2020.)

8. Department of Health, Education, and Welfare (1978). Public Health Service Personnel Instruction 1 CC29.9 Public Health Service Flag, Department of Health, Education, and Welfare T. S. PHS-CC 261, 18 May 1978. https://dcp.psc. gov/ccmis/ccis/documents/CCPM29 9 1.pdf. (Pregledano 17. travnja 2017.)

9. Du Payrat, A. (2000). Album des pavillons nationaux et des marques distinctives / National flags and distinctive markings. Brest: Service Hydrographique et Océanographique de la Marine, Brest 2000.

10. Figsbee, A. (1856). The Maritime Flags and Standards of All Nations Together With a Geographical Sketch. New York: A. Ranney.

11. Flaggenbuch (Fla. B.), (1926). Berlin: Reichswehrministerium Marineleitung.

12. Flaggenbuch (Fla. B.), (1939). Berlin: Oberkommando der Kriegsmarine.

13. Friends of the 1799 Lazaretto Interpretive Museum. https://www.1799lazaretto. com/. (Pregledano 13. ožujka 2020.)

14. Gaedechens, C. F. (1855). Der freien und Hansestadt Hamburg Wappen, Siegel, Flagge und Cocarde. Hamburg: Nolte \& Köhler. (dostupno na https://books. google.hr/books?id=smgAAAAAcAAI)

15. Giadach Axt, S. (2020). A flag for Coronavirus, Facebook, 18. ožujka 2020. https://www.facebook.com/photo.php?fbid=2782195628493027\&set=ecnf.10 0001078510066\&type $=3 \&$ theater. (Pregledano 24.03.2020.) 
16. Gidrografičeski departament Morskago ministerstva (1869). Альбом итандартов, флагов и вымпелов Российской империи, европейских и внеевропейских государств. Sankt-Peterburg: Gidrografičeski departament Morskago ministerstva.

17. Heimer, Ž. (2013). Identitet Oružanih snaga Republike Hrvatske iskazan zastavama vojnih postrojbi u Domovinskom ratu i nakon njega. Doktorska disertacija, Filozofski fakultet, Sveučilište u Zagrebu.

18. Heraldica Slovenica (2020a). Izobesimo zastavo v znak podpore boju proti okužbi s koronavirusom SARS-CoV-2 oz. bolezni COVID-19. Heraldica Slovenica, Ljubljana, 15. ožujka 2020. http://www.heraldica-slovenica.si/. (Pregledano 16. ožujka 2020.)

19. Heraldica Slovenica (2020b). Boj proti koronavirusu ima tudi svojo zastavo. Heraldica Slovenica, Ljubljana, 25. ožujka 2020. http://www.heraldica-slovenica.si/protikoroni.php. (Pregledano 28. ožujka 2020.)

20. Holland L. E. (1953). The Development of Signalling in the Royal Navy. The Mariner's Mirror 39 (1): 5-26.

21. Hribovšek, A. (2020). Coronavirus (COVID-19) and Flags. The Vexilloid Tabloid. Portland, Oregon: Portland Flag Association, Issue 81:8.

22. Kariyasu, N. (2000). Quarantine Flags (Japan). Flags of the World. https://www. crwflags.com/fotw/flags/jp -qtine.html. (Pregledano 15. siječnja 2020.)

23. Kennedy, M. (2020). Brazil's Christ The Redeemer Lit Up With Flags OfCountries Battling Coronavirus, National Public Radio Online, 19. ožujka 2020. https:// www.npr.org/sections/coronavirus-live-updates/2020/03/19/818557823/brazils-christ-the-redeemer-lit-up-with-flags-of-countries-battling-coronavirus. (Pristupljeno 21. ožujka 2020.)

24. Kent, B. (2009). Flag Signalling at Sea, in: Hall, J. (Ed.). Proceedings of the XIX International Congress of Vexillology, York, 23-27 July 2001. London: Flag Institute.

25. Kingdom of Tonga (1988). Quarantine Regulations, CAP. 77A, 26 Feb 1926, 1988 Revised Edition. http://legislation.to/Tonga/DATA/SUB/1988-077-06/ QuarantineRegulations.pdf. (Pregledano 5. veljače 2012.)

26. Lang, S. (1994). Dubrovnik's Tradition of Excellence in Medicine. Croatian Medical Journal, 35 (2): 67.

27. Lomantsov, V. Anatolyevich (2010). Ведомственные флаги Российской империи и прочие морские флаги (часть 1), Vexillographia-Флаги России, Orenburg: Русский Центр флаговедения и геральдики - Russian Centre of Vexillology and Heraldry. http://www.vexillographia.ru/russia/EmpirVed.htm. (Pregledano 10. prosinca 2019.)

28. Le Gras, M. A. (1858). Album des Pavillons, guidons, flammes de toutes les puissances maritimes. Paris: Depot des Cartes et Plans de la Marine.

29. McCandless, B. and Grosvenor, G. (1917). Flags of the World (Our Flag Number). National Geographic Magazine, XXXII (4): 281-420. 
30. National Imagery and Mapping Agency (2003). International Code of Signals for Visual, Sound, and Radio Communications (Pub. 102), United States Edition, 1969 Edition (Revised 2003). Bethesda, Maryland: National Imagery and Mapping Agency.

31. Norie, J. W. and Hobbs, J. S. (1848.). Three Hundred and Six Illustrations of the Maritime Flags of All Nations. London: C. Wilson.

32. Online Biblija (2012). Kršćanska sadašnjost, Zagreb. https://biblija.ks.hr. (Pregledano 30. ožujka 2020.)

33. Pedersen, C. F. (1971). The international flag book in color. New York: Morrow.

34. Pierre (1990). Album des pavillons nationaux et des marques distinctives des états et des principales organisations internationales. Brest: Service Hydrographique et Océanographique de la Marine.

35. Preble, G. H. (1872). Our Flag. Origin and Progress of the Flag of the United States of America with an Introductory Account of the Symbols, Standards, Banners and Flags of Ancient and Modern Nations. Albany: Joel Munsell.

36. RiceFeed (2020). @ricefeed, Facebook, 05. ožuka 2020. https://www.facebook. com/ricefeed/photos/mask-communication-now-admired-online-the-masterpiece-of-a-filipino-artist-for-c/2739872849579788/. (Pregledano 10. ožujka 2020.)

37. Republic of the Philippines Department of Health (2007). Administrative Order No. 118-C (s. 1992), aka Revised Quarantine Rules and Regulations. http://www. medco.gov.ph/ciqs/quarantine-h.htm. (Pregledano 20. prosinca 2007.)

38. Slovenske novice (2020). Pobuda: storimo to kot britanska kraljica (Ma. M.), 15. ožujka 2020. https://www.slovenskenovice.si/novice/slovenija/clanek/pobuda-storimo-isto-kot-britanska-kraljica-289039. (Pregledano 20. ožujka 2020.)

39. Splošna bolnica Celje (2020). Slovenska zastava boja proti koronavirusu, Facebo$o k$, 2. travnja 2020. https://www.facebook.com/521048471750596/photos/a.5 31493460706097/804299496758824/?type=3\&theater. (Pregledano 3. travnja 2020.)

40. Smith, W. (1975). Flag through the Ages and Across the World. New York: McGrawHill.

41. Times.si (2020). Izobesimo zastavo in s tem pokažimo, da smo ostali doma (I. M.), 15. ožujka 2020. http://www.times.si/slovenija/izobesimo-zastavo-in-s-tem-pokazimo-da-smo-ostali-doma--0b4f1839775fe2849851897aa7d0b9a42cb26424. html. (Pregledano 20. ožujka 2020.) 
Pregledni rad

\title{
Epidemic Vexillology - The Use of Flags in Control and Prevention of Infectious Disease Prevention
}

\author{
Željko Heimer \\ Croatian Heraldic and Vexillologic Association, Zagreb, Croatia \\ e-mail: zheimer@gmail.com
}

\begin{abstract}
The paper presents a short historic review of flags used for control, and as a means of control and fight against epidemics, along with the use of flags as symbols of health risk and quarantine, and their development. It presents examples of flags of national services competent for health and sanitary control and quarantine through history. Particular attention is given to the current pandemic of the Severe Acute Respiratory Syndrome named COVID-19, thus the paper presents the use of national flags as solidarity symbols with affected nations and development of newly designed flags symbolizing solidarity with health workers and others fighting against corona, escalating in 2020.
\end{abstract}

Key words: vexillology, quarantine, quarantine signal flag, health and sanitary services ensign, national flag, white flag, struggle against corona flag. 